\title{
Study of Some Biological Indicators of Soil in the Zone of Technogenic Factor (on the Example of Cement Plant "Holcim"-Azerbaijan)
}

\author{
L.A. Aliyeva*, I.X. Babayeva, S.Y. Qasimova and V.K. Isayeva \\ Institute of Microbiology of ANAS, Azerbaijan \\ *Corresponding author
}

\section{A B S T R A C T}

\section{Keywords \\ Biological indicators, \\ Microorgamizms, \\ Enzyme activity, \\ Soil pollution, \\ Toxic effect \\ Article Info \\ Accepted: \\ 18 February 2019 \\ Available Online: \\ 10 March 2019}

\section{Introduction}

The rapidly increasing rates of anthropogenic degradation of natural and artificial natural communities, which are characteristic of our time, have a complex impact on all components of the soil. As a result of technogenic pollution, many natural systems, including soils, are changed or destroyed, which ultimately leads to the loss of their ecological and production functions, as well as fertility-their main and most valuable property $(2,3)$. The main source of biotopes are the emissions resulting from the activities of factories. For example, the cement industry owns most of the gaseous, liquid and solid waste. The process of soil pollution is completely different from water and air pollution. The soil, having a more complicated and complex structure, responds to contamination by imbalance between its components, formed over a long period of time. Soil properties lead to the fact that pollutants remain in the soil long after contamination $(4,5,6)$. On the use of biochemical and biological methods to study the ecological state of soils, as well as changes in the composition of the microbial community has accumulated a significant amount of information. As is known, the 
biological activity of the soil takes the lead in biomonitoring and soil biodiagnosis. Such indicators of biological activity of soils as parameters of accumulation of some products of activity of soil organisms, the number of different groups of soil biota, the activity of the main processes associated with the cycle of elements are often used $(1,6)$.

An important role in soil biodiagnosis plays the definition of soil respiration and enzyme activity as the indicators of the functioning of the total biota. Various methods are used to study the biological activity of soils: biochemical, microbiological, chemical and physiological (2).

The aim of the present work was to study some indicators of biological activity of soils affected by industrial pollution, which was first carried out in the area of the cement plant "Holcim" - a large cement-producing plant located in Garadagh District of Azerbaijan.

\section{Materials and Methods}

"Holcim" (Azerbaijan) is a part of Lafarge Holcim Group, which is one of the world's leading suppliers of cement and aggregates. "Holcim" is one of the leading cement and clinker manufacturing company in Azerbaijan (Fig. 1). The object of the study was graybrown soil samples taken from five sites located at different distances from the cement plant. The first soil sample was taken at a distance of $100 \mathrm{~m}$, the second - at a distance of $500 \mathrm{~m}$, the third - at a distance of $1500 \mathrm{~m}$, the fourth - at a distance of $2500 \mathrm{~m}$, the fifth $-5000 \mathrm{~m}$ from the border of the cement plant, taken as a control. Biological activity of soils was estimated by quantitative characteristic of microbiota (8), degree of urea decomposition, intensity of soil respiration and enzyme activity (7).

Biotesting of soil samples was carried out according to the standard procedure.
Representatives of unicellular green algae, planktonic crustaceans and soil nematodes were used as test objects. The toxicity index of the factor was calculated by Kabirov R. R.

\section{Results and Discussion}

The analysis of the quantitative composition of the microbiota of soil samples (Table 1) showed that the number of microorganisms belonging to different taxonomic groups varies depending on the place of taking soil samples: there is a decrease in the number of microorganisms compared with the control zone in I, II, III, IV soils sites. As can be seen from the table, the quantitative composition of microorganisms belonging to different taxonomic groups has changed to some extent in all soil samples of the studied areas. The number of bacteria and micromycetes decreases in all soil samples. However, there is a slight decrease in the number of fungi compared to the control. These indicators also suggest that fungi are more resistant to contamination than bacteria.

In the course of the studies, there was a change in the biological activity of the studied soils. Thus, in soil samples (I, II, III), located at different distances from the cement plant, the indicators were consistently low. The average value was observed in soil samples IV and $\mathrm{V}$, indicating a slight negative effect of cement plant emissions. The decrease in the rate of ammonia release and the blue staining of the indicator paper was an indicator of a decline in biological activity. As a result, the process of urea metabolism in the studied soils is slowing down (tab.2).

The decrease in biological activity in the first, second and third soil samples were assessed as evidence of impaired soil metabolism. This state of the soil creates unfavorable conditions for the life of plants, protozoa and microorganisms. This was reflected in soil samples I and II. 
Studies have found that each type of soil creates a certain level and ratio of enzyme activity, which determines the intensity and direction of soil biochemical processes. In texnogenic landscapes accumulation and transformation of organic matter are manifestations of soil formation, and these processes also occur with the participation of enzymes, among which an important place belongs to the redox enzymes. Enzyme activity is associated with the intensity of soil respiration. In connection with the above, we studied the activity of peroxidase and the intensity of soil respiration of the studied soil samples. As can be seen from the table 3, soil respiration and activity of the enzyme peroxidase of the studied sites were weak compared to the similar indicators for the soils of the control site. Apparently, this can be caused by the presence of heavy metals in these soils, in particular lead, since it is this metal that has a strong effect on the activity of enzymes such as acid phosphatase, malate dehydrogenase and peroxidase.

Toxicity of the studied soils was determined by biotesting. Chlorella vulgaris, Daphnia magna and soil nematodes were used as test objects.

In our experiments, the death of $50 \%$ or more of Dafnia magna and soil nematodes within 96 hours were taken into account as a criteria of toxic action. The data obtained showed that I, II, III, IV soil samples were toxic. In the V soil sample no toxicity was observed. According to the Chlorella data, the toxicity of each of the four soil samples was identified, which makes it possible to calculate the toxicity factor index (ITF). Comparison of the results was carried out by the method of Kabirov (6), the range of 0.91 1.10 was taken as the norm.

Table 1 The number of microorganisms in the soil samples of the investigated areas

\begin{tabular}{|l|c|c|}
\hline \multirow{2}{*}{ Samplingsites } & \multicolumn{2}{|c|}{ The number of microorganisms } \\
\cline { 2 - 3 } & Bacteria $\left(10^{4} \mathrm{CFU} / \mathrm{q}\right)$ & Micromycetes $\left(\mathrm{CFU} / \mathrm{q} 10^{3}\right)$ \\
\hline I & 90 & 58 \\
\hline II & 104 & 60 \\
\hline III & 115 & 62 \\
\hline IV & 120 & 65 \\
\hline V (control) & 132 & 68 \\
\hline
\end{tabular}

Note: I-100 m, II-500 m, III-1500 m, IV-2500 m, V- 5000 v (control), CFU-colony-forming unit

Table.2 Urea decomposition rate in soil samples (2016-2017years)

\begin{tabular}{|c|c|c|c|c|c|}
\hline \multirow[t]{2}{*}{ Years } & \multicolumn{5}{|c|}{ Biological activity in soil samples } \\
\hline & I & II & III & IV & V (control) \\
\hline 2016 & low & low & low & medium & medium \\
\hline 2017 & low & low & low & medium & medium \\
\hline
\end{tabular}


Table.3 Peroxidase activity and of soil respiration in the studied areas

\begin{tabular}{|l|c|c|c|c|c|}
\hline Soil samples & I & II & III & IV & V (control) \\
\hline $\begin{array}{l}\text { Peroxidase, } \\
\text { activity purpurogallin, } \\
\text { (mq) (2016) }\end{array}$ & 1,8 & 1,83 & 1,83 & 1,90 & 1,92 \\
\hline $\begin{array}{l}\text { Soil respiration, } \\
\text { (mq/100q/h) (2016) }\end{array}$ & 0,63 & 0,63 & 0,66 & 0,72 & 0,81 \\
\hline $\begin{array}{l}\text { Peroxidase, } \\
\text { activitypurpurogallin, } \\
\text { (mq) (2017) }\end{array}$ & 1,78 & 1,81 & 1,82 & 1,92 & 1,92 \\
\hline $\begin{array}{l}\text { Soil respiration, } \\
\text { (mq/100q/h) 2017 }\end{array}$ & 0,62 & 0,64 & 0,65 & 0,71 & 0,80 \\
\hline \multicolumn{102}{|c|}{$\mathbf{C O}_{2}$} & & & & & \\
\hline
\end{tabular}

Table.4 Toxicity of the soil samples

\begin{tabular}{|c|c|c|c|c|}
\hline \multirow{2}{*}{ Soil samples } & \multicolumn{4}{|c|}{ toxicity } \\
\cline { 2 - 5 } & DafniaMagna, \% & Soil & \multicolumn{2}{c|}{ Chlorellavulgaris } \\
\hline I & 83 & 64 & TFI & Degree of toxicity \\
\hline II & 77 & 60 & 0,3 & IV \\
\hline III & 70 & 57 & 0,5 & III \\
\hline IV & 60 & 54 & 0,7 & II \\
\hline V(control) & 43 & 44 & 0,96 & II \\
\hline
\end{tabular}

Note: TFI- toxicity factor index; I-norm, II- weak, III - medium,IV - high

Fig.1 Cement plant "Holcim"

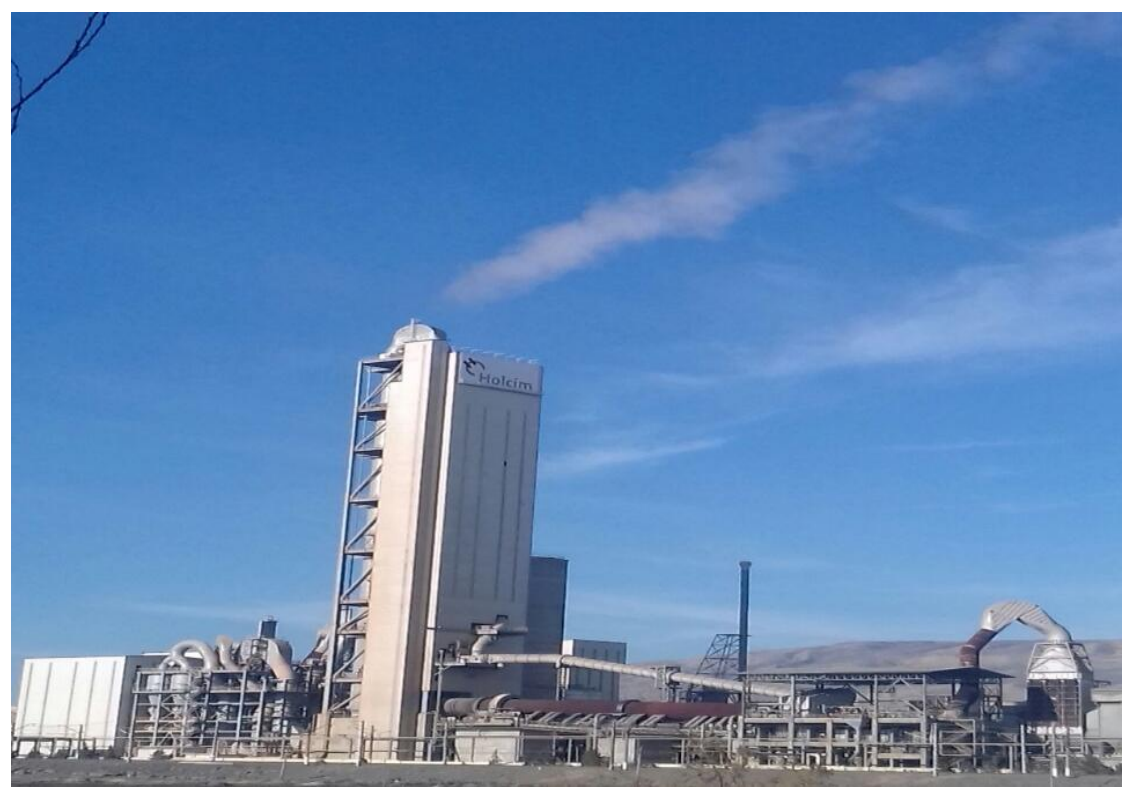


The results show that soil samples from all four sites have toxic effects on Dafnia Magna and soil nematodes (Table 4).

The data on biotesting obtained on Chlorella showed the following: in III and IV soil samples weak, in II - medium, in I-m - high toxicity was observed.

In conclusion, the results of biotesting may indicate the presence of toxic effects, which are probably due to soil contamination as a result of the functioning of the cement plant. Therefore, indicators of biological activity of soils can be used in environmental monitoring of technogenically disturbed areas.

\section{References}

1. Aristovskaya T.V., Chugunova M.V. 1989. Rapid method for determining the biological activity of soil. Soil science, 11:142-147.

2. Babayev A.H. 2011. Soil quality monitoring and environmental control. Baku, publishing house "Law", 263.

3. Bakhshaliyeva K.F. 2017. General characteristics of mycobiota of technogenic soils. Proceedings of the Institute of Microbiology of ANAS, 15,1: 279-287.

4. Vetrova S.N. 1991. Ecological and trophic characteristics of soil nematodes in the conditions of industrial pollution. Abstracts of the scientific conference "Evolutionary theory and problems of phytohelminthology", Moscow, Pp. 2526.

5. Isabekova B.S., Bekbolotova K.A., Mambetova G.A. 2014. Influence of cement production on the environment. Proceedings of KSTU named after. I. Razzakova, 33:485-486.

6. Kabirov R.R. 1997. Development and use of multicomponent test system for assessing the toxicity of the soil cover of urban areas. Ecology, 6:13-15.

7. Kazakova N. A. 2014. Changes in microbial composition and soil toxicity in the zone of influence of cement production emissions. Eurasian Union of scientists, 4(3): 71-72.

8. Netrusov A.I., Egorova M.A., Zakharchuk L.M. 2005. Practicum on Microbiology. Moscow: Academy, 604.

\section{How to cite this article:}

Aliyeva, L.A., I.X. Babayeva, S.Y. Qasimova and Isayeva, V.K. 2019. Study of Some Biological Indicators of Soil in the Zone of Technogenic Factor (on the Example of Cement Plant "Holcim"-Azerbaijan). Int.J.Curr.Microbiol.App.Sci. 8(03): 2103-2107. doi: https://doi.org/10.20546/ijcmas.2019.803.250 